\title{
Does the Tax System Reduce Tax Evasion in Light of the Governance Mechanisms? Evidence From Jordan
}

\author{
Ashraf Bataineh $^{1}$ \\ ${ }^{1}$ Department of Financial and Administrative Sciences, AL-Balqa Applied University/ Irbid University College, \\ Jordan \\ Correspondence: Dr. Ashraf Bataineh, Department of Financial and Administrative Sciences, AL-Balqa Applied \\ University/ Irbid University College, Jordan. E-mail: bataineh_ashraf@bau.edu.jo
}

Received: December 1, 2020

Accepted: December 31, 2020

Online Published: January 14, 2021

doi:10.5430/rwe.v12n2p99

URL: https://doi.org/10.5430/rwe.v12n2p99

\begin{abstract}
This study aims to measure the impact of tax system elements on reducing the tax evasion, in light of the governance mechanisms in Jordan. The study sample consists of (140) tax auditors at the Jordanian Income tax and sales department, and to achieve the study objectives the researcher designed a questionnaire and distributed it on the study sample members. Study results show that elements of the tax system (tax legislations, tax administration, and Taxpayer) have a positive impact on reducing the tax evasion, in light of governance mechanisms. study recommends the need to raise the tax awareness level among members of the Taxpayer, work to reduce the continuation of making adjustments on tax laws and legislation, and give a sufficient period of time to ensure that desired economic and social impact being achieved from these adjustments, with the need to announce the official statistics of tax evasion's figures and ratios, because the unofficial statistics on tax evasion have been tarnished by some exaggeration where work should concentrate on increasing penalties of tax evaders.
\end{abstract}

Keywords: governance mechanisms, Jordan taxpayers, tax administration, tax evasion, tax legislation, tax system

\section{Introduction}

Taxes consider one of the most important and oldest financial resources for many world countries, because it represent a real source that contributes mainly to cover the growing government spending in the various economic and social areas by helping to reduce the financing burdens of these countries. It contributes to the social justice through distribution of incomes and wealth among individuals, and addresses the economic crises such as inflation and recession (Mohammad, 2014). The role of tax system manifested in the increase of tax revenues and the impact on economic variables, such as savings, consumption, volume of investments, and employment which leads to the recovery and development of national economy (Jmam, 2010).

In general, tax administration lies between tax legislation and taxpayers as three elements of the tax system structure. One of the tax administration's Jurisdictions is to simplify and clarify the rules of tax legislation and implement it properly and effectively, in order to protect the rights of State on one hand and the rights of taxpayers on the other hand. It's also the specialty of Tax Administration to propose several amendments to the tax legislation which lead the tax system to a degree of mastery and ultimately will help the society to achieve its economic, social, and other objectives (Yacoub, 2014).

The phenomenon of tax evasion considers one of the main reasons for the existence of so-called tax gap that prevents the conjunction of tax system elements represented in tax legislation, tax administration, and the Taxpayer. Many world countries are seriously interested in studying this phenomenon to identify its causes, methods, and size in order to fill the shortfall in tax revenue (Hanna \& Marcus, 2003).

Therefore, developed and developing countries alike suffer from tax evasion phenomenon and use many methods to fight it, such as tightening the drafting of tax laws, increasing tax awareness, tightening control, fighting corruption, and implementing the tax governance mechanisms, where the study of (Jordan Economic and Social Council, 2014) indicates that tax evasion size in developing countries exceeds the size in developed countries due to high tax rates, huge size of informal economy, unauthorized employment, used accounting method, and high rate of evasion cases. It's known that tax evasion phenomenon limit the ability of Governments to provide revenues needed to finance the 
economic development process.

The existence of tax evasion phenomenon associated with the existence of tax itself and the tax system elements are working hard to fight this phenomenon, in order to minimize its severity and effects (Nasser, 2010). The researcher tries through this study to highlight the role of tax system elements to reduce the tax evasion phenomenon in Jordan, in light of implementing the governance mechanisms which reflects positively on the Jordanian national economy, where at the end of the study researcher presents some suggestions and recommendations that help decision makers to take as basic measures to fight the tax evasion phenomenon in the world countries, in general and Jordan as a developing country in particular.

The level of significant of this study due to the great role that tax system plays in achieving the objectives of economic and social development plans of the Jordanian state, through the formulation of an integrated tax system to create a Taxpayer committed and aware of tax justice, as well as the role that tax system plays in the service and development of society which achieves a culture of voluntary commitment to taxpayers. This comes through the improvement of legislative and working environment by the Jordanian state through the implementation of governance mechanisms, such as transparency, discipline, and accountability which contribute positively and effectively to create an integrated tax system.

The study aims to investigate the concept and level of significant of corporate governance and to identify the possibility of implementing it in the tax chamber, as well as its impact on activating methods to prevent and fight the tax evasion. The study is also making an effort to participate in the dispute and discussion about whether the tax system will have impact on reducing the tax evasion, in the light of governance mechanism existence. In particular, this study will try to answer the following question:

"Does the tax system reduce tax evasion, in light of Jordan's governance mechanisms?"

\section{Literature Review}

In general, many previous studies addressed the effectiveness of tax systems elements, as well as the topic of tax system governance and its relationship with the tax evasion while some other studies addressed the reasons and methods that lead to the tax evasion phenomenon, but didn't find any study that address the measurement of tax system impact with its basic elements on reducing the tax evasion, in light of the governance mechanisms existence. The most important studies that had a direct relationship with the variables of this study include:

The Study of (Al-Rawashdeh \& Al-Bawab, 2019) aimed to identify the impact of institutional governance principles on reducing the tax evasion in Jordan. The most important results of study showed an impact of the institutional governance principles on reducing the tax evasion in Jordan, and the study recommended the need to issue legislations to implement the institutional governance principles and give courses and sessions to the relevant parties to publicize the level of significant of institutional governance principles and its positive impact on tax accountants. The study of (Al-Qudah, 2016) seek to identify the effectiveness level of sales tax system with its three elements (tax systems, tax procedures and control, tax legislations) and show its combined impact on tax revenues. The most important results showed that tax system in Jordan enjoys a high degree of effectiveness, and that tax procedures and control and also tax legislation enjoys a middle degree of effectiveness, The most important recommendations of the study called for the review of some tax legislation by reducing the tax rates on commodities as well as increasing tax rates on high-luxury goods, and also recommended to update the direct tax control mechanisms.

On the other hand, the study of Jordan Economic and Social Council (2014) aimed to analyze the tax system in Jordan and study the factors that affect the increase in tax burden, identify the reasons of tax evasion and the methods used by taxpayers, and the need to estimate the extent of losses that result from increase in taxes and its impact on the national economy. The study used Multiple Indicators and Multiple Causes Mode, which is a special model that used in researches related to the phenomenon of tax evasion as well as other statistical and economic methods. The most important study results represented in identifying the reasons that drive taxpayers to take part in the tax evasion, most notably is the lack of state tightening to impose punishments on tax evaders and the unavailability of data and information base on the taxpayers' activities, and at the end the study recommended to increase penalties on evaders and also recommended to build a database for all workers in Jordan. The study of (Mansour \& Ali, 2013) aimed to show the role of corporate governance on reducing the tax evasion by implementing it on the Federal Tax Office of Republic of Sudan, as one of the developing countries. The study results showed that most taxpayers don't keep proper and systematic accounting books and records, and that accounting systems implemented in the economic units are tarnished by a type of weakness or incompleteness which lead to the tax evasion. Study results also found obstacles between the implementation of governance rules and the tax evasion, the implementation of governance 
rules reduce the tax evasion. The study arrived to a set of recommendations, the most noticeable was the need to train tax auditors in the Tax Office on the corporate governance system, the need of all those responsible to abide by the regular accounting books and records, and to deepen the compliance culture with the agreed transparency laws and standards.

In a different perspective, the study of (Wahab \& Holland, 2012) analyzed the relationship between tax planning and corporate governance mechanisms, and its impact on the value of companies that trade its names on the stock exchange. The study results found a significant contribution of tax planning on maximizing the corporate value through the implementation of governance mechanisms, due to nonexistence of information between corporate managers and internal auditors, and the study included recommendations, the most important was the need to implement the tax planning strategies and governance mechanisms, in order for companies to achieve improvements in their financial performance, where the study of (Armstrong, et. al, 2015) came after it to show the relationship level between corporate governance, management incentives, and the tax evasion. The study used quarterly regression method to analyze the study data which have been collected from a sample of U.S. companies available in Compustat for the consecutive financial years (2007-2011). The most important results showed a positive relationship between the financial development of U.S. companies, the council's independency, and the tax evasion phenomenon. Study results also indicated that corporate governance work on reducing the high levels of tax evasion.

The study of (Jensen, et. al, 2012) used several operational criteria to assess the adequacy level of tax management policies in the area of tax governance, where researchers addressed the costs of tax commitment and tax collection costs, and the study analyzed the methods and policies for fighting tax evasion. The most important study results indicated that achievement of tax revenues comes through raising the tax commitment level, and that efficiency criteria of tax administration represented in the implementation of tax commitment strategy and the use of information technology in the tax collection process. But the study of (Schneider, et. al, 2008) dealt with tax rates and tax evasion through the analysis and experimentation in Italy, where the study results found a relationship between tax evasion and the tax burden; especially in the long term, the existence of a relationship between tax evasion and tax burden and the average tax rate in Italy, and the existence of relationship between the imposed punishments on tax evasion and the disclosure of this punishment, from one side and tax rates and tax evasion size, on the other side.

Finally, the study of (Hannah, 2005) came to show the possibility of implementing the governance principles on tax policies and the tax system structure, and the study results found that tax administration suffers from many shortcomings, where it's possible to eliminate these problems through the implementation of corporate governance mechanisms, and that tax administration considers one of the most important problems that face tax policy, where the tax law has contributed significantly to the governance of tax administration, especially in regard to the relationship between tax administration and taxpayers. The results also highlighted that many governance mechanisms aren't implemented inside the tax administration, such as the principle of disclosure and transparency and the principle of senior management efficiency.

This study differs from the previous studies in the fact that some of those studies made connection between the governance and financial reports, financial performance, and tax revenues' collection without addressing its relationship with the reduction of tax evasion, while other studies focused, in general on the reasons and methods that lead to the phenomenon of tax evasion. These studies didn't address the measurements of tax system impact; with its basic elements on reducing the tax evasion in Jordan, in light of the governance mechanisms. The researcher conducted this study due to the absence of official data on the ratio and size of tax evasion and the lack of studies related to the study topic in Jordan. Therefore, this study seeks to take into account the results and recommendations of previous studies in the effectiveness of tax system with its three elements on reducing the phenomenon of tax evasion, in light of implementing the tax governance mechanisms and its ability to achieve the best desired results in the various different aspects.

\section{Conceptual Framework}

\subsection{Tax System}

The tax system is defined as a practical formulation and translation of all tax strategies in different countries of the world to achieve the goals of countries Crandall (2010). The tax generally considers as a branch of accounting, where it involves preparation of financial statements to estimate the taxable income of individuals and therefore determine the amount of taxes that taxpayers must pay according to the tax law, and also the tax system is closely associated with the law as it imposed and collected, in accordance with methods specified by law (AlAdham, et. al, 2016). Therefore, the performance level of this system is the dominant factor in the embodiment level of tax policy 
objectives on the ground because tax system objectives, no matter how ambitious and no matter how its technical tools are well organized, prepared, and organized but it came to meet the highest interests of society members, in light of the political, social, economic, and financial conditions of the state and society (Palan, et. al, 2013).

As a result of the above laws, changes, and developments and in light of the economic changes that world undergoing today, most countries and especially developing countries seek to attract and encourage investment as one of the most important instruments of economic growth. Jordan is one of those countries that have worked hard, at various levels to achieve the sustainable development goals through the adoption of a series of economic reforms, where most notably the important reforms it has introduced to its tax system, in order to come up with an effective tax policy in line with the pursued economic policy which continuously encourages enterprises to invest and expand. Therefore, the survival of tax system in any country depends on three main aspects:

\subsubsection{Tax Legislations}

Tax legislation is represented by laws and legislation that define the philosophy and objectives of tax system, whether it's financial, economic, political, or social where these tax legislation and laws are characterized by justice, appropriateness, and savings (Ahmed, 2009). Tax legislation is defined as formation of tax policy's principles and rules; in the form of laws to achieve its objectives. Tax legislation must be well drafted to prevent tax evasion of taxpayers and also tax laws must be flexible to adapt with economic conditions of the state (Hajjar, 2006).

Tax legislation is one of the legislative tools used by the state to control the tax relationship between the taxpayer and tax auditor, in order to achieve tax fairness and supply the public treasury with funds, where tax legislation used as an essential step to develop the tax system and activate it, because it considers one of the effective elements of corporate governance. The clarity and simplicity comes through tax legislation that corresponds to environmental variables, and the tax legislation differs from other accounting and professional legislation due to the effectiveness of its implementation scope on all tax system's elements, therefore the obligation of tax law will be significant compared with other laws (Abdul Al-Khaliq, 2006).

\subsubsection{Tax Administration}

Tax administration contributes significantly to the effectiveness of tax system, where the best- -conceived tax system will not have value without the support of administration that implements it, therefore the tax administration must ensure the best implementation for tax system and ensure the objective conditions of tax work ethics (Abed-Alsalam, 2011).

The tax administration is a tool for the implementation of tax system, where it's known as the technical and administrative body responsible for implementing the tax legislation through taxation and collection (Caddie, 2003). Therefore, it's possible to say that tax administration role and its field, in light of the contemporary developments is no longer limited to tax accounting only, but its role has expanded to include the implementation of state strategies and objectives fully by addressing the problems of unemployment, raising the level of per capita income, providing the necessary resources to implement the government programs, and attracting and employing the foreign investments in a way that align with the strategies and objectives of the state (Yacoub, 2014).

\subsubsection{Taxpayers}

The Taxpayer represents all ordinary or legal persons who deal with the tax administration, and there is no doubt that legislative environment reform, the development of tax administration, and the inclusiveness of taxpayer is among the structures to achieve a comprehensive tax reform system. It's an expression that means taxpayer who pays taxes, whether this society consists of normal or legal persons (Ibrahim, 2011).

The tax system is a technical formulation of the society's tax policy and designed to achieve its objectives, where a tax system that is suitable to achieve the objectives of specific tax policy in a particular society may not be appropriate to achieve the objectives of a tax policy in another society. The commitment of Taxpayer to transparency contributes to the elimination of administrative and financial corruption, where the stabilization of tax system reduces the tax burden on taxpayers and gives their commitment a kind of conviction and satisfaction (Mohammed, 2014).

\subsection{Tax Evasion}

The tax evasion considers a global phenomenon and its existence have been accompanied by the existence of tax itself, and this phenomenon has become more important since the end of 1970s and the beginning of 1980s, due to the rapid growth and development of the parallel economic activities. Given the important role of taxes in the financial, economic, social, and political aspects, therefore the various tax systems are working to fight the tax 
evasion phenomenon in order to reduce its severity (Nasser, 2010).

Tax evasion represents the general concept that individuals and companies under-report the taxable activities or over-report the deductible expenses. Taxpayers illegally conceal or misreport; otherwise legal economic activities in an attempt to reduce the amount of paid taxes. Tax evasion gives an increase to the tax gap; which known as the monetary difference between revenues that tax authorities would collect if all taxpayers would comply with the tax code, other forms of regulation, and the real collected revenue (Jensen, et. al). (McGee, 2012) defines tax evasion as avoiding tax payments by taxpayers in various legal and illegal ways and methods, taking an advantage of the gaps in prevailing law.

Individuals can escape income taxes by underreporting incomes, overstating deductions, exemptions, or credits, failing to file appropriate tax returns, even engaging in trade to avoid taxes. Similarly, indirect taxes like the value-added taxes (VAT) present numerous opportunities for evasion and indeed firms can simply fail to register for VAT, underreport sales, or present fake invoices that allow them to understate their tax liabilities (Crocker \& Slemrod, 2005; Goerke \& Runkel, 2006).

There are two types of tax evasion, the first type called illegal evasion or tax fraud and occurs whenever tax laws are violated, such as customs evasion and includes all fraudulent methods and the financial fraud methods that taxpayers use to avoid the tax payment. The second type called legitimate evasion and doesn't involve a violation of tax laws but it occurs whenever taxpayers benefit from the loopholes or gaps that may exist in the tax code, where taxpayers enter through it to avoid the obligation of paying taxes. The table below shows the differences between the two types of tax evasion (Al-Saadani, 2010).

Table 1. Differences between tax evasion types

\begin{tabular}{ccc}
\hline Declaration & Legal tax evasion & Illegal tax evasion \\
\hline Legal position & "Legal" by exploiting legal loopholes & "Illegal" by breaking the law \\
\hline Penalties & Got penalties & No penalties \\
\hline Tax position & No taxes imposed & Loss of public rights \\
\hline Action & Adjust or rewrite the law & Raise awareness of those charged with \\
& & legislation and laws \\
\hline Tax auditor role & Prepare a memo for the central research & Prepare a memo for the Anti-Evasion \\
& department & Service \\
\hline
\end{tabular}

The difficulty and complexity of laws and legislation that govern the tax system, the various procedures of collecting taxes, taxpayers feeling of the high burden of taxes and fees imposed on them, and their feeling about not benefiting from services provided by the State leads to increase the phenomenon of tax evasion. There are very few studies related to the phenomenon of tax evasion in Jordan, and these have been limited to analysing the causes of income tax evasion and its impact on the economy, therefore the value or size of tax evasion; in general has not been determined in those studies.

The researcher through this study tries to highlight the impact of tax system elements on reducing the phenomenon of tax evasion, in light of the implementation of governance mechanisms in Jordan, which reflects positively on the Jordanian national economy. The researcher at the end of study will provide some suggestions and recommendations to decision makers to take as procedures to fight the phenomenon of tax evasion in Jordan.

\subsection{Tax System Governance}

Before talking about the tax governance, the concept of governance had to be clarified where (Ibrahim, 2011) defines it as a set of laws, regulations, and decisions that aimed to achieve the quality and excellence of performance. Accordingly, (Atiyah, 2014) defines tax governance as a set of mechanisms and principles practiced by the tax administration, which control the flow of tax system elements according to principles of justice, transparency, discipline, accountability of responsibilities, and other basic mechanisms and principles.

The achievement of governance in any tax system requires the availability of most data and information based on taxation, methods used for connection, or estimation of taxes objectively and to achieve the principles and mechanisms of tax system governance (transparency, discipline, and accountability of responsibilities) the tax 
administration should collect and standardize the instructions needed for the implementation of tax examination process. This can be done by publishing these instructions and announcing it, with the need to update it continuously and send it to taxpayers, where these instructions can help taxpayers whenever they prepare the tax decisions and submit it to the tax department (Atiyah, 2014).

The governance principles and mechanisms inside the tax department contribute significantly to the elimination of various forms of administrative corruption, and control and rationalize the poor performance, whether for individuals who work in the tax administration, or some accountants, financial consultants, and lawyers who provide tax advice and consulting to taxpayers, in order to avoid taxation or tax evasion.

\section{Methods \& Data}

\subsection{Methodology}

This field study depends on its methodology on the descriptive analytical method, and also derived its data and information from many sources in order to test hypotheses and achieve the study objectives, which include:

- Secondary sources: these sources include a full survey of previous studies, books, scientific papers, publications, university thesis and dissertations, documents, and official statistics that are directly related to the study topic.

- Primary sources: this source includes the collection of study data directly from the field, in order to design a questionnaire that contains all the study variables, where the researcher distributed the questionnaire on the study sample to collect data and test hypotheses, and analyse all data and results through the use of statistical analysis program (SPSS).

\subsection{Data Environment}

The study population consists of all 380 tax auditors in the Jordanian Income and Sales Tax Department (www.istd.gov.jo), and the researcher relied on a sample of study society to obtain the required data for the study purposes, which were selected from the study population mentioned above. The researcher distributed (190) questionnaires on the tax auditors with $50 \%$ of the population, and (140) tax auditors returned questionnaires after filling out all the required information in the questionnaire's dimensions.

\section{Research Hypotheses}

The study will test the following hypotheses:

$\mathbf{H}_{\mathbf{0 1}}$ : Tax system has a positive significant effect on reducing the tax evasion in Jordan.

$\mathbf{H}_{\mathbf{0 2}}$ : Tax system has a positive significant effect on the governance mechanisms in Jordan.

$\mathbf{H}_{03}$ : Tax system has a positive significant effect on the tax evasion, in light of the governance mechanisms existence in Jordan.

\section{Analysis \& Findings}

\subsection{Instrument Tests}

\subsubsection{Instrument Validity Coefficients}

Face validity aims to ensure that study instrument items can lead to collect data accurately, and to achieve this validity the researcher presented the study instrument on a number of specialized Jordanian universities' faculty members who were asked to remove any confusion from its items by adding, modifying, or deleting whatever they see appropriate, and after obtaining their suggestions the study instrument was modified according to it. The content validity was also confirmed by ensured that each variable of the study is accurately represented by a set of items that measure it, and to achieve this validity the researcher calculated the Pearson Correlation Coefficient to measure the relationship between each item and the degree of variable that belong to it, and between variables and the overall degree of study instrument. The statistical criterion shows items validity to measure and maintain the variable whenever the correlation coefficient is more than (30\%) and significant at level $(\alpha \geq 0.05)$ (Sekaran \& Bougie, 2010). Table 2 shows that all correlation coefficient values are greater than (30\%) and significant at level $(\alpha \geq 0.05)$, which is acceptable for study purposes and shows that study instrument has content validity. 
Table 2. Content validity

\begin{tabular}{|c|c|c|c|c|c|c|c|c|c|c|}
\hline \multirow[t]{2}{*}{ Items } & \multicolumn{2}{|c|}{ Tax legislations } & \multicolumn{2}{|c|}{$\begin{array}{c}\text { Tax } \\
\text { Administration }\end{array}$} & \multicolumn{2}{|c|}{ Taxpayer } & \multicolumn{2}{|c|}{$\begin{array}{l}\text { Tax evasion } \\
\text { reduction }\end{array}$} & \multicolumn{2}{|c|}{$\begin{array}{c}\text { Governance } \\
\text { mechanisms } \\
\text { implementation }\end{array}$} \\
\hline & Correlation & Sig. & Correlation & Sig. & Correlation & Sig. & Correlation & Sig. & Correlation & Sig. \\
\hline 1 & 0.558 & 0.000 & 0.435 & 0.000 & 0.754 & 0.000 & 0.467 & 0.000 & 0.641 & 0.000 \\
\hline 2 & 0.564 & 0.000 & 0.485 & 0.000 & 0.775 & 0.000 & 0.461 & 0.000 & 0.727 & 0.000 \\
\hline 3 & 0.499 & 0.000 & 0.688 & 0.000 & 0.811 & 0.000 & 0.653 & 0.000 & 0.481 & 0.000 \\
\hline 4 & 0.455 & 0.000 & 0.601 & 0.000 & 0.558 & 0.000 & 0.723 & 0.000 & 0.779 & 0.000 \\
\hline 5 & 0.526 & 0.000 & 0.630 & 0.000 & 0.449 & 0.000 & 0.697 & 0.000 & 0.755 & 0.000 \\
\hline 6 & 0.556 & 0.000 & & & & & 0.670 & 0.000 & 0.674 & 0.000 \\
\hline 7 & & & & & & & 0.638 & 0.000 & 0.501 & 0.000 \\
\hline 8 & & & & & & & 0.419 & 0.000 & & \\
\hline & \multicolumn{2}{|c|}{ With instrument } & \multicolumn{2}{|c|}{ With instrument } & \multicolumn{2}{|c|}{ With instrument } & \multicolumn{2}{|c|}{ With instrument } & \multicolumn{2}{|c|}{ With instrument } \\
\hline & 0.674 & 0.000 & 0.649 & 0.000 & 0.741 & 0.000 & 0.704 & 0.000 & 0.824 & 0.000 \\
\hline
\end{tabular}

\subsubsection{Reliability Analysis}

The reliability analysis means that same results can be obtained when re-analyzing the study by using the questionnaire (study tool) under similar conditions and on individuals themselves. To verify the reliability, the internal consistency has been calculated using the Cornbach Alpha Coefficient equation for the study instrument as a whole and for each variable separately. The statistical results indicate that any variable that has a Cornbach Alpha result of $(\geq 0.70)$ is statistically reliable (Sekaran \& Bougie, 2010). Table 3 shows that internal consistency coefficient values for all variables were greater than (70\%) and significant at level $(\alpha \geq 0.05)$, and showed the reliability of study instrument.

Table 3. Reliability Test

\begin{tabular}{|c|c|c|c|}
\hline Part & Variables & No. of items & Cornbach Alpha \\
\hline \multirow{4}{*}{ Tax System } & Tax Legislations & 6 & 0.821 \\
\hline & Tax Administration & 5 & 0.812 \\
\hline & Taxpayer & 5 & 0.883 \\
\hline & Tax System as a whole & 16 & 0.875 \\
\hline Reduce Tax Evasion & & 8 & 0.831 \\
\hline Existence Governance & & 7 & 0.777 \\
\hline \multicolumn{4}{|l|}{ Mechanisms } \\
\hline Total & & 31 & 0.883 \\
\hline
\end{tabular}

\subsubsection{Factor Analysis}

To test the factorial validity of study instrument, Factor Analysis has been implemented by using the principal comment method on sample members' responses, and calculated the Loadings values for each extracted factor from the variable, and also the Communalities values, after rotating it in the Varimax method. Table 4 shows that all Communalities and Loadings values for all the extracted factors are high, where the statistical references indicated the acceptance of Communalities values if it's higher than (0.35) (Sekaran \& Bougie, 2010). 
Table 4. Loadings and Communalities values

\begin{tabular}{|c|c|c|c|c|c|c|c|c|}
\hline \multicolumn{3}{|c|}{$\begin{array}{c}\text { Tax Legislations } \\
\text { \%of Variance: }(26.811 \%)\end{array}$} & \multicolumn{3}{|c|}{$\begin{array}{c}\text { Tax Administration } \\
\text { \%of Variance: }(37.225 \%)\end{array}$} & \multicolumn{3}{|c|}{$\begin{array}{c}\text { Taxpayer } \\
\text { \%of Variance: }(44.955 \%)\end{array}$} \\
\hline $\begin{array}{l}\mathbf{N} \\
\mathbf{o .}\end{array}$ & Loadings & Communalities & No. & Loadings & Communalities & No. & Loadings & Communalities \\
\hline 1 & 0.765 & 0.594 & 1 & 0.707 & 0.504 & 1 & 0.729 & 0.534 \\
\hline 2 & 0.509 & 0.432 & 2 & 0.460 & 0.409 & 2 & 0.730 & 0.554 \\
\hline 3 & 0.483 & 0.454 & 3 & 0.492 & 0.461 & 3 & 0.806 & 0.665 \\
\hline 4 & 0.512 & 0.462 & 4 & 0.798 & 0.662 & 4 & 0.481 & 0.442 \\
\hline 5 & 0.592 & 0.447 & 5 & 0.830 & 0.708 & 5 & 0.554 & 0.435 \\
\hline 6 & 0.700 & 0.529 & & & & & & \\
\hline
\end{tabular}

\subsection{Regression Analysis Assumptions}

Prior to the testing process of study hypotheses using multiple linear regression coefficient models, it was necessary to confirm the validity of data and verify the suitability of study model, because the assumptions of multiple linear regressions specify that data of study variables should be naturally distributed and that independent variables are free of the linear interference problem. To test the normal distribution of data, researchers conducted Skewness test and Kolmogorov-Smirnov One-Sample Test to ensure that data follow the normal distribution, and that decision base will be as indicated by (Mordkoff, 2011) who stated that data follow the normal distribution if the Skewness values of variables confined between $3 \pm$ and that significant level of the $\mathrm{Z}$ values in $\mathrm{K}-\mathrm{S}$ test were greater than 5\%.Table 9 shows that all study variables follow the normal distribution, where the Skewness coefficient values where between (0.988-0.070-), which fall within the statistical standard of normal distribution $( \pm 3)$. It also noticed that significant levels in the K-S test were greater than (5\%) for all study variables and for the instrument as a whole, therefore data of study variables follow the normal distribution, and valid for the multiple linear regression analysis.

Table 5. Normal distribution test

\begin{tabular}{lcccc}
\hline \multirow{2}{*}{\multicolumn{1}{c}{ Variables }} & \multirow{2}{*}{ Skewness } & \multicolumn{2}{c}{ Kolmogorov-Smirnov } & \multirow{2}{*}{ Results } \\
\cline { 3 - 5 } & & Kolmogorov-Smirnov Z & Asymp. Sig. (2-tailed) & \\
\hline Tax legislations & -0.070 & 1.489 & 0.124 & Normal distribution \\
\hline Tax Administration & -0.295 & 1.911 & 0.111 & Normal distribution \\
\hline Taxpayer & -0.812 & 1.516 & 0.120 & Normal distribution \\
\hline Tax system as a whole & -0.510 & 0.926 & 0.358 & Normal distribution \\
\hline Tax evasion reduction & -0.618 & 1.465 & 0.127 & Normal distribution \\
\hline Governance mechanisms & -0.988 & 1.198 & 0.114 & Normal distribution \\
\hline Instrument as a whole & -0.601 & 0.615 & 0.843 & Normal distribution \\
\hline
\end{tabular}

Researchers confirmed that independent variables between one another are free of the linear interference or Collinearity problem, and to verify these issue researchers used the exchangeable correlation matrix and the Variance Inflation Factor (VIF) for each independent variable. The statistical decision rule as indicated by (Sekaran \& Bougie, 2010) stated the absence of a Collinearity problem whenever the correlation value between two different variables is lower than $(70 \%)$, values of Contrast inflation factor don't exceed (10), and the allowable variation test value is greater than (0.20). Table 6 shows nonexistence of Collinearity problem between the independent study variables, where the exchangeable correlation matrix between the independent variables were less than (70\%) and the VIF values were lower than (10). 
Table 6. Spearman Correlation Matrix \& Autocorrelation Test

\begin{tabular}{cccccc}
\hline Variable & $\begin{array}{c}\text { Tax } \\
\text { legislations }\end{array}$ & Tax Administration & Taxpayer & VIF & Tolerance \\
\hline Tax legislations & 1.000 & $0.303^{* *}$ & $0.308^{* *}$ & 1.149 & 0.870 \\
\hline $\begin{array}{c}\text { Tax } \\
\text { Administration }\end{array}$ & $0.303^{* *}$ & 1.000 & $0.532^{* *}$ & 1.454 & 0.688 \\
\hline Taxpayer & $0.308^{* *}$ & $0.532^{* *}$ & 1.000 & 1.439 & 0.695 \\
\hline
\end{tabular}

**Correlation is significant at level 0.01 (2-tailed)

\subsection{Hypotheses Test}

Testing first hypothesis: this hypothesis indicates that "Tax system has a positive significant effect on reducing the tax evasion in Jordan".

To test this hypothesis, researchers used the multiple linear regression analysis to identify the impact of tax system (tax legislations, tax administration, Taxpayer) on reducing the tax evasion in Jordan, and the results show in the following table:

Table 7. Multiple linear regression for tax system effect on reducing tax evasion

\begin{tabular}{ccccccc}
\hline Variables & Expected sign & Coefficient & t-Statistic & Prob. & Tolerance & VIF \\
\hline (Constant) & \multicolumn{1}{c}{1.250} & 3.226 & 0.002 & & \\
\hline Tax legislations & $+/-$ & 0.212 & 2.063 & 0.041 & 0.870 & 1.149 \\
\hline Tax Administration & $+/-$ & 0.240 & 2.534 & 0.012 & 0.688 & 1.454 \\
\hline Taxpayer & $+/-$ & 0.227 & 2.379 & 0.019 & 0.695 & 1.439 \\
\hline $\mathrm{R}$ & 0.476 & F-statistic & 13.307 \\
\hline R-squared & 0.227 & Prob. (F-statistic) & 0.000 \\
\hline Adjusted R Square & 0.210 & & \\
\hline & Predictors: (Constant) tax legislations, tax administration, Taxpayer \\
& Dependent Variable: Reduction of tax evasion \\
\hline
\end{tabular}

Table 7 shows the most important elements of the tax system that affect the reduction of tax evasion was the dimension of tax administration with (24\%), then the dimension of Taxpayer with (22.7\%), and in the third place in terms of impact came the dimension of tax legislation (21.2\%), which shows the need for the Income and Sales Tax department in Jordan to pay attention to the tax system to reduce tax evasion. Based on the above, the initial hypothesis is rejected and will accept the alternative hypothesis "there is a positive effect of the tax system on reducing the tax evasion in Jordan".

Testing Second hypothesis: this hypothesis indicates that "Tax system has a positive significant effect on the governance mechanisms in Jordan".

To test this hypothesis, researchers used the multiple linear regression analysis to identify the impact of tax system (tax legislations, tax administration, Taxpayer) on the implementation of governance mechanisms at the Income and Sales Tax department in Jordan, and the results show in the following table: 
Table 8. Multiple linear regression for tax system effect on the implementation of governance mechanisms

\begin{tabular}{|c|c|c|c|c|c|c|}
\hline Variables & Expected sign & Coefficient & t-Statistic & Prob. & Tolerance & VIF \\
\hline (Constant) & & 0.653 & 1.693 & 0.093 & & \\
\hline Tax Legislations & $+/-$ & 0.222 & 2.166 & 0.032 & 0.870 & 1.149 \\
\hline Tax Administration & $+/-$ & 0.215 & 2.289 & 0.024 & 0.688 & 1.454 \\
\hline Taxpayer & $+/-$ & 0.384 & 4.035 & 0.000 & 0.695 & 1.439 \\
\hline $\mathrm{R}$ & \multicolumn{2}{|l|}{0.559} & \multicolumn{2}{|l|}{ F-statistic } & \multicolumn{2}{|c|}{20.579} \\
\hline R-squared & \multicolumn{2}{|l|}{0.312} & \multicolumn{2}{|c|}{ Prob. (F-statistic) } & \multicolumn{2}{|c|}{0.000} \\
\hline Adjusted R Square & \multicolumn{2}{|l|}{0.297} & & & & \\
\hline
\end{tabular}

Predictors: (Constant) tax legislations, tax administration, Taxpayer

Dependent Variable: implementation of governance mechanisms

Table 8 shows the most important elements of the tax system that affect the implementation of governance mechanisms was the dimension of Taxpayer with (38.4\%), then the dimension of tax legislation with (22.2\%), and in the third place in terms of impact came the dimension of tax administration (21.5\%), which shows the need for the Income and Sales Tax department in Jordan to pay attention to the tax system to achieve the highest level of governance mechanisms implementation. Based on the above, the initial hypothesis is rejected and will accept the alternative hypothesis "there is a positive effect of the tax system on implementing the governance mechanisms in Jordan".

Testing third hypothesis: this hypothesis indicates that "Tax system has a positive significant effect on the tax evasion, in light of the governance mechanisms existence in Jordan".

To test this hypothesis, researchers used the multiple linear regression analysis to identify the impact of tax system (tax legislations, tax administration, Taxpayer) on reducing the tax evasion, in light of the implementation of governance mechanisms at the Income and Sales Tax department in Jordan, and the results show in the following table:

Table 9. Results of the multiple hierarchy regression of the tax system impact on reducing tax evasion, in light of the governance mechanisms implementation

\begin{tabular}{|c|c|c|c|c|c|c|c|c|c|c|}
\hline & Independent Variable & Coefficient & 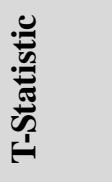 & Prob. & (R) & $\left(\mathbf{R}^{2}\right)$ & 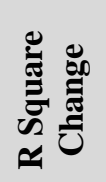 & 玨蒂 & I & Prob. \\
\hline \multirow{4}{*}{$\begin{array}{l}3 \\
0 \\
0 \\
0 \\
0\end{array}$} & (Constant) & 1.250 & 3.226 & 0.002 & \multirow{4}{*}{ 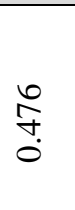 } & \multirow{4}{*}{$\hat{\tilde{઼}}$} & \multirow{4}{*}{ సิ } & \multirow{4}{*}{$\begin{array}{l}\hat{d} \\
\text { m. } \\
\stackrel{n}{n}\end{array}$} & \multirow{4}{*}{$\begin{array}{l}\hat{D} \\
\text { m. } \\
\stackrel{-}{-}\end{array}$} & \multirow{4}{*}{\begin{tabular}{l}
8 \\
\hdashline \\
0
\end{tabular}} \\
\hline & Tax Legislations & 0.212 & 2.063 & 0.041 & & & & & & \\
\hline & Tax Administration & 0.240 & 2.534 & 0.012 & & & & & & \\
\hline & Taxpayer & 0.227 & 2.379 & 0.019 & & & & & & \\
\hline \multirow{8}{*}{$\begin{array}{l}3 \\
\frac{3}{2} \\
\frac{2}{1} \\
N\end{array}$} & (Constant) & 1.046 & 2.801 & 0.006 & \multirow{5}{*}{$\begin{array}{l}\text { +े } \\
\stackrel{n}{0}\end{array}$} & \multirow{5}{*}{$\begin{array}{l}\text { Oे } \\
\text { లె } \\
0\end{array}$} & \multirow{5}{*}{$\frac{n}{0}$} & \multirow{5}{*}{ 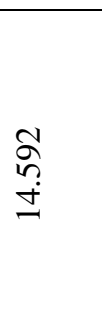 } & \multirow{5}{*}{$\begin{array}{l}\hat{\infty} \\
\stackrel{+}{+} \\
\dot{J}\end{array}$} & \multirow{5}{*}{$\stackrel{8}{8}$} \\
\hline & Tax Legislations & 0.143 & 1.432 & 0.154 & & & & & & \\
\hline & Tax Administration & 0.172 & 1.874 & 0.063 & & & & & & \\
\hline & Taxpayer & 0.107 & 1.113 & 0.168 & & & & & & \\
\hline & $\begin{array}{l}\text { Governance mechanisms } \\
\text { implementation }\end{array}$ & 0.313 & 3.806 & 0.000 & & & & & & \\
\hline & \multicolumn{10}{|c|}{ Predictors: (Constant) tax legislations, tax administration, Taxpayer } \\
\hline & \multicolumn{10}{|c|}{ Predictors: (Constant), tax legislations, tax administration, Taxpayer, governance mechanisms implementation } \\
\hline & \multicolumn{10}{|c|}{ Dependent Variable: reduction of tax evasion } \\
\hline
\end{tabular}


Table 9 shows the ability of moderator variable (governance mechanisms implementation) to totally or partially represent the dimensions of independent variable on influencing the reduction of tax evasion, results indicated that governance mechanisms implementation (tax legislations, tax administration, Taxpayer) was totally represented on influencing the reduction of tax evasion, where the T-value was statistically significant before entering the moderator variable (governance mechanisms implementation) and after entering it into the regression model, it became statistically insignificant, which means that governance mechanisms implementation would replace the tax system with its dimensions in reducing the tax evasion, and indicated the need of Income and Sales Tax department to pay attention to the tax system, in light of the governance mechanisms implementation due to its role in reducing the tax evasion in Jordan. Based on the above, the nihilistic hypothesis will be rejected and will accept the alternative hypothesis "there is an impact of the tax system on reducing the tax evasion in light of the governance mechanisms implementation in Jordan".

\section{Discussion}

Study results indicate a positive significant effect of the Tax system on reducing tax evasion, in light of the governance mechanisms existence in Jordan and this result agrees with the study results of (Al-Rawashdeh \& Al-Bawab, 2019) which showed an impact of the institutional governance principles on reducing the tax evasion in Jordan. Study results came in agreement with the results of (Armstrong, et. al, 2015) study which found a positive relationship between the financial development of U.S. companies, the council's independency, and the tax evasion phenomenon. Study results also indicated that corporate governance work on reducing the high levels of tax evasion, and came in consistent with the results of (Al-Qudah, 2016) study which found positive correlation between the effectiveness level of tax system at its three elements (tax systems, tax procedures and control, tax legislations) and tax revenues. This study disagree with the results of (Mansour \& Ali, 2013) study which showed that most accounting systems implemented in the economic units are tarnished by a type of weakness or incompleteness which lead to the tax evasion. As a result of developments and in light of the economic changes that world experiencing today, most countries and especially developing countries seek to attract and encourage investment as one of the most important instruments of economic growth. Jordan is one of those countries that have worked hard, at various levels to achieve the sustainable development goals through the adoption of a series of economic reforms, where most notably the important reforms it has introduced on its tax system in order to come up with an effective tax policy in line with the pursued economic policy which continuously encourages enterprises to invest and expand.

\section{Conclusions \& Recommendations}

The study results indicate the existence of a middle effect of tax system elements combined (tax legislations, tax administration \& Taxpayer) on reducing the tax evasion at the Jordanian Income tax and sales department. Results also showed that tax administration is the most influencing elements of tax system on the reduction of tax evasion because the tax administration conducts sudden inspections on the taxpayers' books, through tax auditors. The element of Taxpayer comes next in the degree of importance by following the transparency standards in dealing with the Taxpayer, then the element of tax legislation came third, in terms of effect because tax legislations work to avoid legal loopholes or gaps that open the door to tax evasion by amending legislation related to the estimation and collection of taxes, in a way that reduces the phenomenon of tax evasion, which shows the need for Jordanian Income tax and sales department to pay attention to the tax system to reduce the tax evasion.

Study results indicate an impact of the combined elements of tax system on the implementation of governance mechanisms in the income and sales tax department, and results of statistical analysis showed a large proportion of changes that happen in the implementation of governance mechanisms are the result of changes in the tax system, where governance mechanisms work to achieve the transparency and freedom of information in the tax system. Governance mechanisms also work for early detection of the low levels financial and administrative performance, which demonstrates the importance of tax system on implementing the governance mechanisms at the Jordanian Income tax and sales department.

Finally, study results showed that governance mechanisms implementation has contributed to improving the impact between tax system elements and the reduction of tax evasion at the Income tax and sales department in Jordan, where after entering the governance mechanisms variable to the regression model in the study data analysis, the model became statistically insignificant which means that implementation of governance mechanisms eliminates the need for tax system; in its dimensions to reduce the tax evasion.

Based on the results of data analysis and hypotheses testing, the study made the following recommendations, where it recommended the need to raise the tax awareness level among members of the Taxpayer by expanding the information and cultural framework, building a real understanding of the tax commitment principles, and fighting the 
phenomenon of tax evasion as the main challenge that faces the tax reform process. The success of anti-evasion methods depends on the tax system and the efficiency of tax administration in enforcing the tax laws and legislations, and also these methods won't give the desired results if they aren't accompanied by a campaign to raise the awareness of taxpayers about their duties and rights. The conviction of taxpayers that money they pay to the government; in the form of taxes don't go in vain but it used for reform, development, and improvement is a key factor for not avoiding tax evasion. Therefore, all efforts must be made to develop and activate the tax system in order to achieve the desired tax reform, by implementing the correct tax governance rules on all employees of the tax administration and the Taxpayer.

Study also recommend reducing the modifications and amendments on tax laws and legislations and give sufficient time to ensure that the desired economic and social impact of these amendments occurs or not, where the continuous amendments to laws and legislations give the impression of injustice and that it's only intended to increase the collection. It also calls for the need to announce the official statistics that related to the figures, rates, and ratios of tax evasion, because the informal statistics related to the tax evasion topic have been a little overrated, in addition to tax evasion, and that rumors of tax evasion may in fact be either tax avoidance that isn't forbidden by the law due to the existence of loopholes and gaps in the current tax laws and legislations that allow it to occur or tax exemptions. Therefore, tightening the penalties on income and sales taxes' evaders and defame them with emphasizing the need to facilitate and speed up the litigation processes, where this slander and defamation is expected to receive social and political support, and lead to the provision of additional financial sources to the treasury.

\section{Study Limitations \& Scope}

The sample of this study was limited to tax auditors in the Jordanian Income and Sales Tax Department, due to lack of official data on the ratio and size of tax evasion because activities related to tax evasion are necessarily secret and difficult to access, and due to lack of studies on this topic in Jordan. This study also examined three components of the tax system (tax legislation, tax administration, and tax society) to see its impact on reducing the tax evasion, in light of governance mechanisms. In regard to data source, the current study uses the questionnaire as an instrument to measure the study variables but still the current study suggested that future studies should take into account the above constraints, in order to provide a more comprehensive result and to validate the current results.

This study will help to encourage researchers and scholars in the tax accounting field to conduct additional studies related to the governance and tax evasion mechanisms. It will draw the attention of policy makers and practitioners about the use of governance mechanisms; in general and its positive roles in controlling state tax revenues; in particular. This study also directs and guides the tax legislator to take into account the governance mechanisms whenever making any legal amendments, by involving the tax society and community in these amendments.

\section{References}

Abdul Khaliq, O. (2006, June). The impact of tax legislation provisions on the structural composition of deferred taxes and its reflection on the size of book burden and the efficiency of accounting disclosure. Tax Conference (11), 32 .

Abed-Alsalam, W. (2011). The effectiveness of tax system in Algeria. Unpublished Master Thesis, University of Qasedi Merbah, The Faculty of Economics \& Commerce, Algeria.

Al-Adham, M. A. A., Abukhadijeh, M. A., \& Qasem, M. F. (2016). Tax evasion and tax awareness evidence from Jordan. International Business Research, 9(12), 65-75. https://doi.org/10.5539/ibr.v9n12p65

Alm, J. (2012). Measuring, explaining, and controlling tax evasion: lessons from theory, experiments, and field studies. International Tax and Public Finance, 19(1), 54-77. https://doi.org/10.1007/s10797-011-9171-2

Al-Qudah, M. (2016). The effectiveness level of sales tax system in Jordan and its impact on the revenue size, from the standpoint of auditors at the Department of Income and Sales Tax. Journal of the Islamic University for Economic and Administrative Studies, 1(24), 16-33. https://doi.org/10.12816/0025722

Al-Rawashdeh, H., \& Al-Bawab, A. (2019). The Impact of The Corporate Governance Principles in Reducing of Tax evasion in Jordan. Al- Anbar University Journal of Economic and Administrative Sciences, 11(25), 386-404.

Al-Saadani, M. (2010). Tax Evasion: Its Concept, Dimensions, forms, and prescribed Sanctions. Finance and Commerce Journal, 2(50), 4-17.

Al-Sadiq, A., \& Mansour, A. (2013). The role of corporate governance in reducing tax evasion by application to the Federal Tax Office in Sudan: an analytical field study. Journal of Science and Technology, Humanities and Economics, 14(1), 135-161. 
Armstrong, C. S., Blouin, J. L., Jagolinzer, A. D., \& Larcker, D. F. (2015). Corporate governance, incentives, and tax avoidance. Journal of Accounting and Economics, 60(1), 1-17. https://doi.org/10.1016/j.jacceco.2015.02.003

Atiyah, M. (2014). The development of performance for the Egyptian tax administration through its implementation of the governance principles-an applied study on the Egyptian Tax Authority with reference to the Islamic approach and international experiences. Tax Conference (21), 2(1), 1-63.

Caddie, A. (2003). The approach into macroeconomic policies, an evaluation analytical study. University Publications Bureau, Algeria.

Crandall, W. J. (2010). Revenue administration: performance measurement in tax administration (No. 2010-2011). International Monetary Fund. https://doi.org/10.5089/9781462316236.005

Crocker, K. J., \& Joel, S. (2005). Corporate tax evasion with agency costs. Journal of Public Economics, 89(9-10), 1593-1610. https://doi.org/10.1016/j.jpubeco.2004.08.003

Goerke, L., \& Marco, R. (2006). Profit tax evasion under oligopoly with endogenous market structure. National Tax Journal, 59(4), 851-857. https://doi.org/10.17310/ntj.2006.4.06

Hajjar, M. (2006). The impact of tax policy on the investment strategy at the foundation - the case of Ben Hammadi Foundation for the manufacture of packaging bags. Unpublished Master Thesis, Mohamed Boudiaf University in Al-Maseilah, Algeria.

Hanna, N., \& Marcos, S. (2003). The role of tax strategies and administrative engineering in activating the quality of tax administration performance. 8th Tax Conference of the Egyptian Society for Public Finance and Taxation, entitled "Income tax reform in light of local and international variables", held from 7-10, December 2003.

Ibrahim, A. (2011). The governance of tax system is a real necessity for tax reform. 17th Tax Conference of evaluation and assessment of the Egyptian Tax System, 3(1), 1-36.

Income and Sales Tax Department (ISTD). Retrieved from www.istd.gov.jo/

Jamam, M. (2010). The tax system and its effects on the economic development - Case study of Algeria. PhD Thesis, Um Al-Bawaqi University, Algeria.

Jensen, J., Wöhlbier, F., \& Generaldirektion Wirtschaft und Finanzen Europäische Kommission (2012). Improving tax governance in EU Member States: Criteria for successful policies (Vol. 114). Publications Office of the European Union

Jordan Economic and Social Council. (2014). Tax Evasion in Jordan, its causes, methods, and size. March Study. Retrieved from www.esc.jo

Mansour, F., \& Ali, A. (2013). The role of corporate governance in reducing tax evasion by implementing it on the Federal Tax Office in Sudan-an analytical and field study. Journal of Science and Technology in Humanities and Economics, 14(1), 135-161

McGee, R. W. (Ed.) (2011). The ethics of tax evasion: Perspectives in theory and practice (2012 ed.). Springer Science \& Business Media

Mohammed, A. (2014). Proposed Approach to the Development of Tax System to Meet the Contemporary Challenges. Scientific Journal of Business and Environmental Studies, 5(1), 199-223.

Mordkoff, J. (2011). The Assumptions of Normality. Retrieved from http://www2.Psychology.uiowa.edu/faculty/mordkoff/GradStats/part\%201/I.07\%20normal.pdf

Nasser, M. (2010). Reasons of Tax Evasion and its Effects on National Economy. Economic Studies, Baseirah center for research, consulting \& educational services, No. 14, pp. 7-16, Algeria.

Palan, R., Murphy, R., \& Chavagneux, C. (2013). Tax havens: How globalization really works. Cornell University Press. https://doi.org/10.7591/9780801468568

Schneider, F., Marzano, E., \& Chiarini, B. (2008). Tax Rates and Tax evasion: an Empirical Analysis of the Structure Aspects and Long-Run Characteristics in Italy, (No. 3447). Discussion Paper Series, The institute for the Study of Labor.

Sekaran, U., \& Bougie, R. (2010). Research Method for Business: a Skill Building Approach. (5th ed). West Sussex: Wiley Publication. 
Wahab, N. S. A., \& Holland, K. (2012). Tax planning, corporate governance and equity value. The British Accounting Review, 44(2), 111-124. https://doi.org/10.1016/j.bar.2012.03.005

Yacoub, O. (2014). Total Quality Management as an approach to improving the efficiency and effectiveness of tax screening. Tax Conference (21), 2.

\section{Copyrights}

Copyright for this article is retained by the author(s), with first publication rights granted to the journal.

This is an open-access article distributed under the terms and conditions of the Creative Commons Attribution license (http://creativecommons.org/licenses/by/4.0/). 